\title{
Comparison of Quorum Sensing Inhibition and Antimicrobial Properties of Some Commercial and Wild Mushrooms Extracted with Supercritical $\mathrm{CO}_{2}$
}

\author{
Sibel Yildiz', Ayşenur Gürgen*1, Sana Tabbouche², Gönül Serdar³, Münevver Sökmen ${ }^{4}$, Ali Osman Kiliç² \\ ${ }^{1}$ Karadeniz Technical University, Faculty of Forestry, Forest Industrial Engineering, Trabzon, Turkey. \\ ${ }^{2}$ Karadeniz Technical University Faculty of Medicine, Department of Medical Microbiology, Trabzon, Turkey. \\ ${ }^{3}$ Karadeniz Technical University, Faculty of Pharmacy, Department of Analytic Chemistry, Trabzon, Turkey. \\ ${ }^{4}$ Konya Food and Agricultural University, Faculty of Engineering and Architecture, Department of Bioengineering, \\ Konya, Turkey. \\ *aysenur.yilmaz@ktu.edu.tr
}

Received: 18 January 2019

Accepted: 13 May 2019

DOI: $10.18466 /$ cbayarfbe. 514436

\begin{abstract}
Recently, bioactive properties of mushrooms have been intensively investigated, and their wealth in bioactive compounds particularly of medicinal properties have increased their consumption. In this study, quorum sensing inhibition and anti-microbial properties of some commercial and wild mushroom species were investigated. Agaricus bisporus species were purchased from three different commercial companies. Laccaria bicolor, Bovista plumbea, Lactarius deliciosus and Boletus edulis were collected from Trabzon, Turkey. Compounds extractions were performed using supercritical fluid extraction $\left(\mathrm{CO}_{2}\right)$ method. Quorum sensing inhibition activity was tested using Chromobacterium violaceum as bacterium-model. Antimicrobial potential of extracts was tested using agar well diffusion method against Staphylococcus aureus, Escherichia coli, Enterococcus faecalis, Pseudomonas aeruginosa, Salmonella Typhimurium, Klebsiella pneumoniae, Proteus mirabilis, Listeria monocytogenes, Candida parapsilosis and Candida albicans. All wild mushroom extracts except for $B$. plumbea inhibited the violacein production of $C$. violaceum. L. bicolor, A. bisporus (1), B. plumbea, A. bisporus (2) extracts inhibited the bacterial growth of $S$. aureus. In addition, $L$. bicolor extract inhibited $K$. pneumoniae and L. monocytogenes whereas $A$. bisporus (2) extract inhibited P. aeruginosa. Among all mushrooms, L. bicolor extract showed remarkable results.
\end{abstract}

Keywords: Antimicrobial activity, cultivated mushroom, quorum sensing inhibition, wild mushroom.

\section{Introduction}

Mushrooms are considered as a powerful source of nutrients for human and many mushroom species are defined as functional foods. They are rich in proteins and amino acids [1], they are low-calorie because of their low fat and high-water compositions [2]. They also include $\beta$-glucan, which promotes the immune system [3] and vitamin D that is essential for bone health [4]. Mushroom contain also biological and physiologically active substances such as phenolic acids [5]. Moreover, mushrooms are cost-effective.

Collection of wild mushroom species becomes a pleasant social activity for some professional or amateur groups in Turkey. Today, the most commonly produced and consumed mushroom specie in Turkey is Agaricus bisporus (J.E. Lange) Imbach. During the last 10 years, mushroom production in Turkey has increased by $54 \%$ from 26.256 tons to 40.874 tons [6]. Scientific studies proved that mushroom contained bioactive compounds with antioxidant, antimicrobial and antidiabetic properties [7, 8]. Further researches should be continued particularly to test and compare species growing in different geographies and various climatic conditions.

Recently, anti-quorum sensing properties are included to the medical properties investigated for mushrooms/plants. Quorum sensing (QS) is a cell-cell communication mechanism used by bacteria to control their community growth between many other bacterial properties. The system permits for each bacterium to perceive the bacterial population growth and to control its own gene expression and regulate its own growth in response to the perceived information [9]. Therefore, the interruption of the QS mechanism may alter the bacterial communication hence may inhibit their growth, which is an important step for the bacterial infection and adherence to surfaces as much as for biofilm formations [10]. 
In this study, quorum sensing inhibition capabilities and anti-microbial properties of some commercial and wild mushrooms extracts are investigated and compared with each other.

\section{Materials and Methods \\ 2.1. Mushrooms}

Wild mushrooms were collected from Trabzon province located in the north eastern part of Turkey and identified by their morphological and their ecological characteristics. Agaricus bisporus mushrooms were purchased from three different commercial companies established in Trabzon and coded from 1 to 3 . Tested mushrooms and their properties were given in Table 1 .

Table 1. Tested mushrooms.

\begin{tabular}{|l|c|c|}
\hline \multicolumn{1}{|c|}{ Mushroom (Code) } & Source & Edibility \\
\hline $\begin{array}{l}\text { Laccaria bicolor } \\
\text { (Maire) P.D. Orton }\end{array}$ & Wild & Edible \\
\hline Bovista plumbea Pers. & Wild & $\begin{array}{c}\text { Edible, not } \\
\text { highly valued }\end{array}$ \\
\hline $\begin{array}{l}\text { Lactarius deliciosus } \\
\text { (L.) Gray }\end{array}$ & Wild & Edible \\
\hline Boletus edulis Bull. & Wild & Edible \\
\hline $\begin{array}{l}\text { Agaricus bisporus J.E. } \\
\text { Lange) Imbach (1) }\end{array}$ & Cultivated & Edible \\
\hline A. bisporus (2) & Cultivated & Edible \\
\hline A. bisporus (3) & Cultivated & Edible \\
\hline
\end{tabular}

Mushroom samples were dried on food-dryer at $40{ }^{\circ} \mathrm{C}$ (Profilo, PFD1350W, Turkey), then were ground in a basic micro-fine grinder and passed through 1millimeter sieve (IKA, WERKE MF10, Germany).

\subsection{Extracts Preparation}

Supercritical $\mathrm{CO}_{2}$ fluid extraction was applied for $10 \mathrm{~g}$ of mushroom powder at 250 bar, $50{ }^{\circ} \mathrm{C}$ for 3 hours (Spe-ed SFE model 7070). $\mathrm{CO}_{2}$ flow rate was $10 \mathrm{~g} / \mathrm{min}$ and ethanol was used as co-solvent with a flow rate of $0.5 \mathrm{~mL} / \mathrm{min}$. The extracts were dissolved as $10 \mathrm{mg} / \mathrm{mL}$ in dimethyl sulfoxide (DMSO) to form working solution.

\subsection{Anti-Quorum Sensing Activity}

Anti-quorum sensing activity was tested against Chromobacterium violaceum (C. violaceum) (Table 2). This bacterium produces a purple pigment called violacein and this production is controlled by the QS system [12]. A compound with anti-quorum sensing property will inhibit the pigment production by $C$. violaceum without altering the bacterial cells growth. Therefore, the investigation of anti-QS activity was tested for the concentrations below the MIC (Minimal Inhibitory Concentration) for each extract, knowing that MIC is the least concentration able to inhibit the bacterial growth. MIC was determined in accordance to the guidelines of the Clinical \& Laboratory Standards Institute (CLSI) [11] using the microdilution method on 96 wells plate, and then the concentration next below the MIC (SubMic) and its next lower concentration were tested for pigment inhibition. Extract concentrations started by $5 \mathrm{mg} / \mathrm{mL}$ and bacterial final concentration was $5 \times 10^{4} \mathrm{CFU} / \mathrm{mL}$. After an incubation of $24 \mathrm{~h}$, the 96 -well plate was dried at $50{ }^{\circ} \mathrm{C}$ for 1 hour, the pigments were dissolved in $200 \mu \mathrm{L}$ of DMSO and left to dissolve for 2 hours on shaker $(225 \mathrm{rpm})$. The pigment solutions were taken to a new 96 well plate and their absorbance were read at $\mathrm{OD}_{585} \mathrm{~nm}$. The same test for each extract was repeated three times, twice for pigment testing and the third was used for plate count agar test to verify the bacterial growth condition. Bacterial count was realized by taking $100 \mu \mathrm{L}$ and spreading it on Mueller Hinton agar and incubating at $37^{\circ} \mathrm{C}$ for $24 \mathrm{~h}$.

Table 2. Tested microorganisms, and their American Type Culture Collection (ATCC) number.

\begin{tabular}{|c|c|c|}
\hline Microorganism & $\begin{array}{c}\text { ATCC } \\
\text { number }\end{array}$ & Used test \\
\hline C. violaceum & 12472 & $\begin{array}{c}\text { Anti-quorum } \\
\text { sensing }\end{array}$ \\
\hline S. aureus & 25923 & \multirow{10}{*}{$\begin{array}{l}\text { Anti-microbial } \\
\text { activity }\end{array}$} \\
\hline E. coli & 25922 & \\
\hline E. faecalis & 29212 & \\
\hline$P$. aeruginosa & 27853 & \\
\hline S. Typhimurium & 14028 & \\
\hline K. pneumoniae & 13883 & \\
\hline P. mirabilis & 7002 & \\
\hline L. monocytogenes & 43251 & \\
\hline C. parapsilosis & 22019 & \\
\hline C. albicans & 10231 & \\
\hline
\end{tabular}

\subsection{Antimicrobial Activity}

Antimicrobial activity was tested using agar well diffusion method in accordance to the guidelines of CLSI on Mueller Hinton agar [11]. The tested microorganisms were given in Table 2.

Microorganisms were obtained from Karadeniz Technical University, Department of Medical Microbiology, Faculty of Health Sciences in Trabzon, Turkey. The tested microorganisms and extracts were applied as $50 \mu \mathrm{L}$ of $10 \mathrm{mg} / \mathrm{mL}$ solutions. Luria Bertani (LB) fluid and agar medium (LABM; United Kingdom) were used for bacterial cultures. DMSO was used for negative control and ampicillin, gentamicin, tetracycline, cefotaxime and amphotericin B were used as positive controls.

Extracts with positive antimicrobial activity were tested for their minimal inhibitory concentration in accordance to the guidelines of the Clinical \& Laboratory Standards Institute (CLSI) on 96 wells plate. The extract concentration started by $5 \mathrm{mg} / \mathrm{mL}$ and bacterial final concentration was $5 \times 10^{4} \mathrm{CFU} / \mathrm{mL}$. The last 2 well were used for growth control (bacteria without extract) and for sterility control (extract without bacteria). 


\section{Results and Discussion}

A positive anti-QS activity is defined as the least concentration able to eliminate the pigment production without altering the bacterial growth. The two concentrations next below the MIC value were tested for each extract. Optical Density (OD) at $585 \mathrm{~nm}$ was determined to evaluate the pigment productions, measurements were repeated twice and their average results were added to the charts. Vanilla was used as a positive control (Figure 4). Anti-QS effect of vanilla was previously optimized and shown to be positive at around $625 \mu \mathrm{g} / \mathrm{mL}$. DMSO was also tested as negative control. Among the mushroom extracts, three wild mushroom extracts have shown anti-QS activity and their activity charts are given in Figure 1-3, respectively.

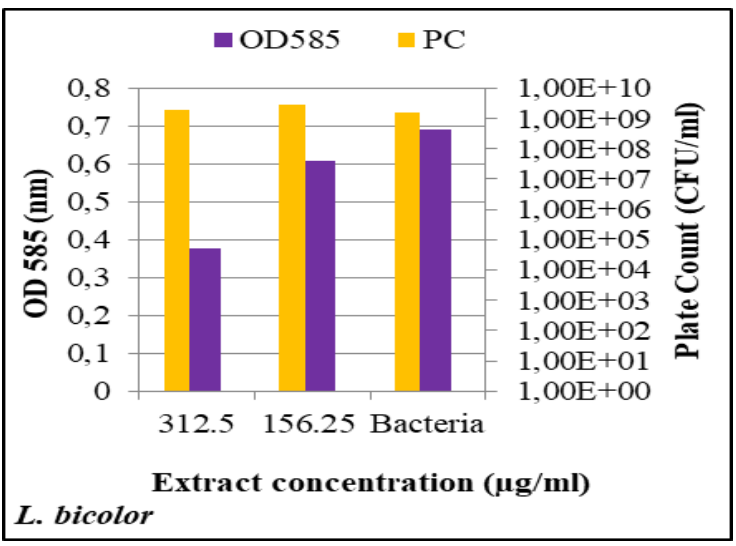

Figure 1. L. bicolor anti-QS activity chart.

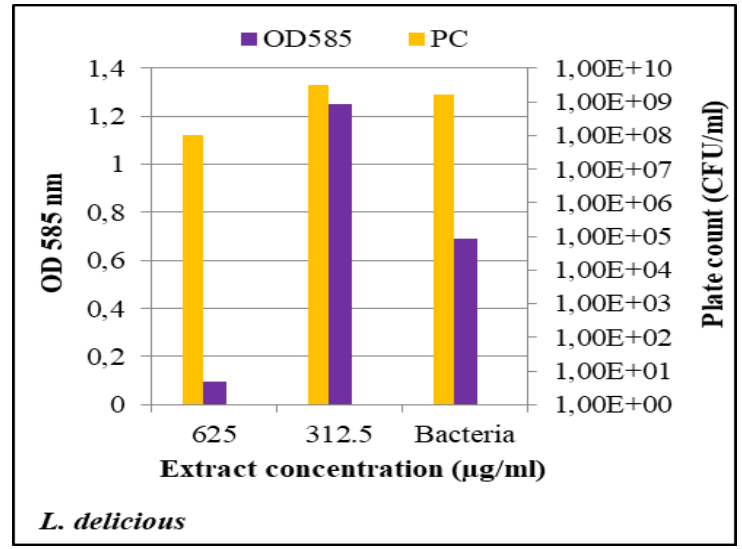

Figure 2. L. deliciosus anti-QS activity chart.

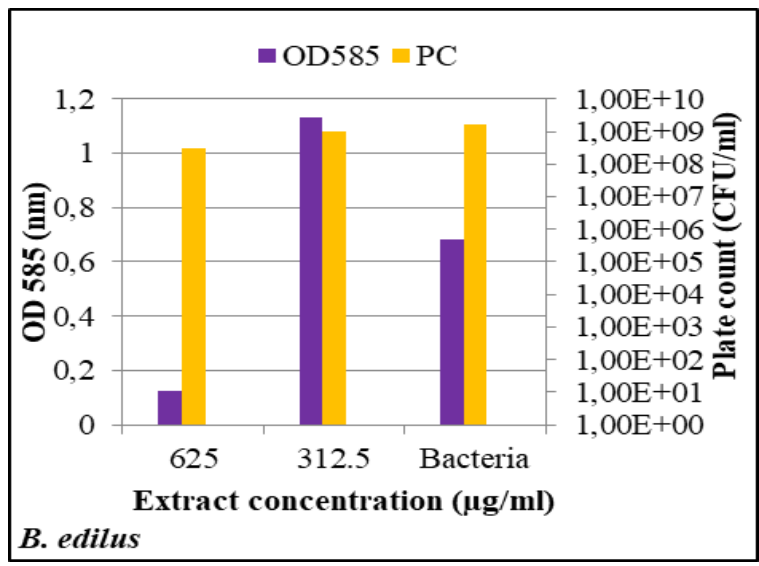

Figure 3. B. edulis anti-QS activity chart.

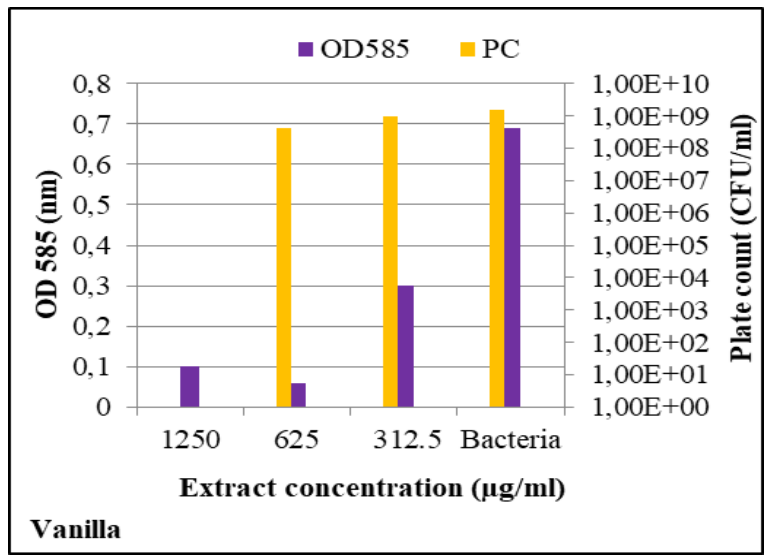

Figure 4. Vanilla anti-QS activity chart.

In this study, three out of four wild mushroom extracts showed anti-QS activity against $C$. violaceum pigment production, they were $L$. bicolor, $L$. deliciosus and $B$. edulis. As shown Figure 1-3, These mushrooms notably decreased the pigment production in comparison to the bacterial growth, which remains invariable or slightly affected. Based on these charts (Figure 1-3), the activities of the mushrooms can be compared with each other as follows; L. deliciosus $>$ B. edulis $>$ L. bicolor. Anti-QS activity was not observed in any of the mushroom samples cultivated in the laboratory. Whereas in other study previously conducted, laboratory-grown mushroom species have shown positive anti-QS activity [13]. However, in the mentioned study, all the conditions were different starting with the grown mushroom species (Pleurotus ostreatus), to the cultivation conditions (the mushrooms were cultivated using different substrates), till the extraction method where organic extraction using methanol was applied [13].

Therefore, it can be concluded that mushroom specie, the substrate used as growth nutrient, the type of extraction and the concentration of studied extracts are highly determining factors concerning anti-QS activity. 
Looking to the results of other studies, Auricularia auricular mushroom pigments showed anti-QS activity on $C$. violaceum [14]. Similarly, Tremella fuciformis mushroom's 75\% (v/v) aqueous methanol extract inhibited violacein production of $C$. violaceum [15].

Moreover, anti-quorum sensing activity of Inonotus obliquus mushroom's aqueous and ethanolic extracts was tested on Pseudomonas aeruginosa [16]. It was reported that both extracts showed positive anti-QS activity. In addition, another study conducted by Soković et al. [17] investigated anti-QS activity of hot water extracts of Agaricus blazei on P. aeruginosa and positive activity was observed [17]. It can be concluded that wild mushrooms constitute a promising source of compounds with anti-QS activity and that more investigations are in need to reveal the properties of these compounds and the conditions needed for their isolation.

In the last decades, significant success was achieved in the treatment and the prevention of microbial infections and this is due to the development of antimicrobial drugs. However, the development of resistance against antimicrobial drugs by some microorganisms has led to the declination of these achievements [18] and day after day new antimicrobial resistance profiles are generated and superbugs are quickly spreading. Therefore, the research for new antimicrobial compounds has become compulsory. Mushrooms, with their wealth in chemical and biological constituents and with their wide presence in the natural environments between all the microbial communities either in competition or in symbiotic interactions make them one of the promising natural resources for antimicrobial compounds. Antimicrobial potential of extracts was tested by agar well diffusion method in this study. In the agar diffusion method, a suitable medium containing the test organism is used with a pit system in which the sample to be tested is present. At the end of the incubation period, if the tested sample is effective, inhibition zones are formed around the pits, where no microorganism reproduction (Figure $5)$.

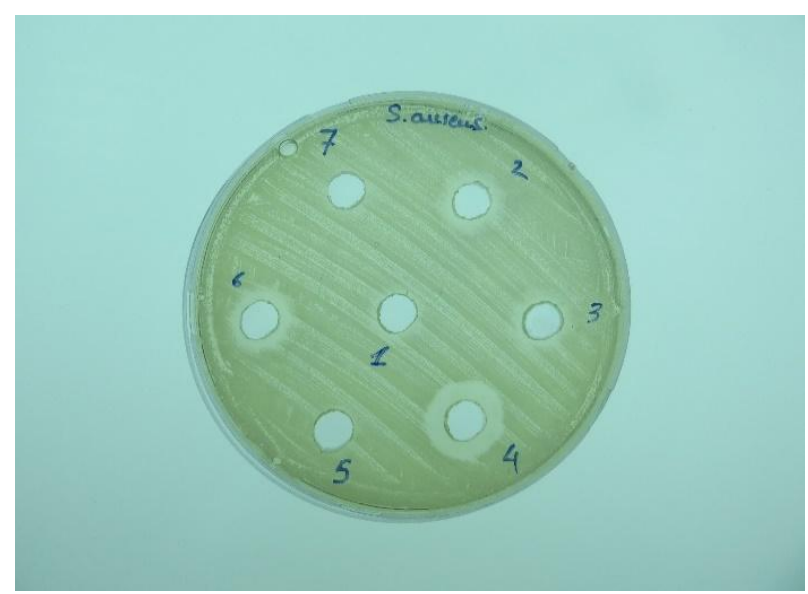

Figure 5. Agar well diffusion assay.

Antimicrobial assay results ( $\mathrm{mm})$ of all tested mushroom extracts and positive controls (antibiotics) are given in Table 3. Taken that the well's diameter (7 $\mathrm{mm}$ ) was subtracted after measuring the inhibition zone diameter.

Table 3. Agar Well Diffusion Results (mm).

\begin{tabular}{|c|c|c|c|c|c|c|c|c|c|c|}
\hline \multirow[b]{2}{*}{ Sample } & \multicolumn{10}{|c|}{ Inhibiton zone (mm) } \\
\hline & 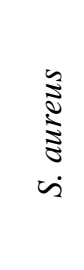 & $\begin{array}{l}\overrightarrow{\tilde{8}} \\
\dot{0}\end{array}$ & $\begin{array}{r}0 \\
0 \\
0 \\
.5 \\
0 \\
0 \\
0 \\
0 \\
0 \\
0\end{array}$ & 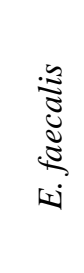 & 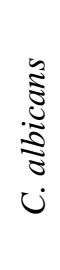 & 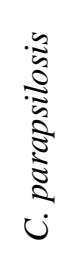 & 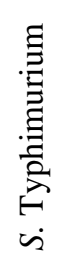 & 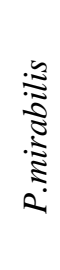 & 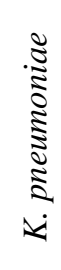 & 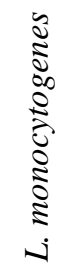 \\
\hline L. bicolor & 2 & 0 & 0 & 0 & 0 & 0 & 0 & 0 & 2 & 1 \\
\hline A. bisporus (1) & 0 & 0 & 0 & 0 & 0 & 0 & 0 & 0 & 0 & 0 \\
\hline L. deliciosus & 0 & 0 & 0 & 0 & 0 & 0 & 0 & 0 & 0 & 0 \\
\hline A. bisporus (2) & 2 & 0 & 0 & 0 & 0 & 0 & 0 & 0 & 0 & 0 \\
\hline B. plumbea & 2 & 0 & 0 & 0 & 0 & 0 & 0 & 0 & 0 & 0 \\
\hline B. edulis & 0 & 0 & 0 & 0 & 0 & 0 & 0 & 0 & 0 & 0 \\
\hline A. bisporus (3) & 2 & 0 & 2 & 0 & 0 & 0 & 0 & 0 & 0 & 0 \\
\hline Ampicillin & $>30$ & $\begin{array}{c}16- \\
17\end{array}$ & $\ldots{ }^{*}$ & $>30$ & $\cdots$ & $\cdots$ & 27 & $\cdots$ & $\cdots$ & $\ldots$ \\
\hline Gentamicin & $\ldots$ & $\ldots$ & $21-22$ & $\ldots$ & $\ldots$ & $\ldots$ & $\ldots$ & $\ldots$ & 21 & $\ldots$ \\
\hline Amphotericin B & $\ldots$ & $\ldots$ & $\ldots$ & $\ldots$ & 30 & $0 * *$ & $\ldots$ & $\ldots$ & $\ldots$ & $\ldots$ \\
\hline Tetracycline & $\ldots$ & $\ldots$ & $\ldots$ & $\ldots$ & $\ldots$ & $\ldots$ & $\ldots$ & $\ldots$ & $\ldots$ & 25 \\
\hline Cefotaxime & $\ldots$ & $\ldots$ & $\ldots$ & $\ldots$ & $\ldots$ & $\ldots$ & $\ldots$ & 37 & $\ldots$ & $\ldots$ \\
\hline
\end{tabular}

* Not tested, **May have acquired bacterial resistance to the used control. The tests were not repeated, as no extract had a positive effect. 
As shown in Table 3, L. bicolor, A. bisporus (2), $B$. plumbea and A. bisporus (3) supercritical $\mathrm{CO}_{2}$ extracts had positive antimicrobial activity. Noticeably, $L$. bicolor showed antimicrobial effect against $K$. pneumoniae and L. monocytogenes microorganisms. Many studies have reported the antimicrobial activity of fungi. For example, ethanol extracts and four fractions of Inonotus sanghuang inhibited Staphylococcus aureus, Bacillus subtilis and Bacillus cereus [19]. A. lanipes showed antimicrobial activity against Micrococcus luteus, Proteus vulgaris, Yersinia enterocolitica, S. aureus, B. subtilis, E. coli, and $C$. albicans microorganisms [20]. Minimum inhibition concentrations (MIC) of the antimicrobial active extracts are given in Table 4.

Table 4. Minimum Inhibition Concentration $(\mu \mathrm{g} / \mathrm{mL})$.

\begin{tabular}{|c|c|c|c|c|c|c|c|}
\hline \multirow{2}{*}{ Sample } & \multicolumn{7}{|c|}{ Minimum Inhibition Concentration $(\mu \mathrm{g} / \mathrm{mL})$} \\
\cline { 2 - 7 } & $\begin{array}{c}S . \\
\text { aureus }\end{array}$ & $\begin{array}{c}\text { E. } \\
\text { coli }\end{array}$ & $\begin{array}{c}\text { P. } \\
\text { aeruginosa }\end{array}$ & $\begin{array}{c}C . \\
\text { albicans }\end{array}$ & $\begin{array}{c}\text { P. } \\
\text { mirabilis }\end{array}$ & $\begin{array}{c}\text { K. } \\
\text { pneumoniae }\end{array}$ & $\begin{array}{c}\text { L. } \\
\text { monocytogenes }\end{array}$ \\
\hline L. bicolor & 156.25 & $\ldots$ & $\ldots$ & $\ldots$ & $\ldots$ & 1250 & 625 \\
\hline A. bisporus $(2)$ & 39.1 & $\ldots$ & $\ldots$ & $\ldots$ & $\ldots$ & $\ldots$ & $\ldots$ \\
\hline B. plumbea & 78.125 & $\ldots$ & $\ldots$ & $\ldots$ & $\ldots$ & $\ldots$ & $\ldots$ \\
\hline A. bisporus $(3)$ & 156.25 & $\ldots$ & 1250 & $\ldots$ & $\ldots$ & $\ldots$ & $\ldots$ \\
\hline Ampicillin & 78.125 & 2500 & $\ldots$ & $\ldots$ & $\ldots$ & $\ldots$ & $\ldots$ \\
\hline Gentamicin & $\ldots$ & $\ldots$ & 1250 & $\ldots$ & $\ldots$ & 156.25 & $\ldots$ \\
\hline Amphotericin B & $\ldots$ & $\ldots$ & $\ldots$ & 78.125 & $\ldots$ & $\ldots$ & $\ldots$ \\
\hline Cefotaxime & $\ldots$ & $\ldots$ & $\ldots$ & $\ldots$ & 9.76 & $\ldots$ & $\ldots$ \\
\hline Tetracycline & $\ldots$ & $\ldots$ & $\ldots$ & $\ldots$ & $\ldots$ & $\ldots$ & 78.125 \\
\hline
\end{tabular}

MIC means the lowest concentration that inhibits bacterial growth. Therefore, a low MIC affirm a better antimicrobial activity of the tested substance. MIC value is also dependent of the purity of the tested substance. In this study, the lowest MIC value was obtained from A. bisporus (2) extract with $39.1 \mu \mathrm{g} / \mathrm{mL}$. The MIC value of $L$. bicolor is higher than the value of A. bisporus (2) MIC value, although it exhibited antimicrobial activity against 4 microorganisms. In a previous study, MIC values of aqueous extracts obtained from 21 wild basidiomycete mushrooms and cultivated mushroom (Pleurotus ostreatus) were reported between 10 and $1524 \mu \mathrm{g} / \mathrm{mL}$ against microorganisms included Listeria innocua, B. cereus, Campylobacter jejuni, E. coli, C. albicans and Aspergillus ochraceus [21].

\section{Conclusion}

In this study, QS inhibition and anti-microbial properties of some commercial and wild mushrooms were investigated. Except for $B$. plumbea, all wild mushroom extracts significantly decreased the violacein production of C. violaceum. L. bicolor, A. bisporus (1), $B$. plumbea and A. bisporus (2) extracts inhibited the growth of $S$. aureus. In addition, L. bicolor extract inhibited $K$. pneumoniae and L. monocytogenes while $A$. bisporus (2) extract inhibited $P$. aeruginosa. Among all mushrooms, L. bicolor showed remarkable results. The evaluation of our results and their comparison with other studies results prove the importance of mushroom as resource for new compounds as mean of antimicrobial and anti-QS activities. These works should be continued with the aim to isolate the active compounds and to test their efficacy with emphasis on the importance of the different conditions surrounding the mushrooms cultivation, growth environment and extraction methods.

\section{Acknowledgement}

This work was supported by Karadeniz Technical University Scientific Research Projects Unit (FHD2015-5373). This study was presented as oral presentation in in 1. International Technological Sciences and Design Symposium, 24-27 June 2018, Giresun, Turkey.

\section{Author's Contributions}

Sibel Yıldız: Drafted the manuscript, conducted the project of this study.

Ayşenur Gürgen: Drafted and wrote the manuscript, obtained the mushrooms and performed the biological experiments.

Sana Tabbouche: Drafted the manuscript, performed anti-microbial and anti-quorum sensing experiments.

Gönül Serdar: Performed Supercritical $\mathrm{CO}_{2}$ extraction of mushrooms.

Münevver Sökmen: Performed Supercritical $\mathrm{CO}_{2}$ extraction of mushrooms.

Ali Osman Kılıç: Performed anti-microbial and antiquorum sensing assay experiments. 


\section{Ethics}

There are no ethical issues after the publication of this manuscript.

\section{References}

1. Lu, X, Brennan, MA, Serventi L, Liu, J, Guan, W, Brennan, C.S 2018. Addition of mushroom powder to pasta enhances the antioxidant content and modulates the predictive glycaemic response of pasta. Food Chemistry; 264: 199-209.

2. Kalač, PA. 2013. review of chemical composition and nutritional value of wild-growing and cultivated mushrooms. Journal of the Science of Food and Agriculture; 93(2), 209-218.

3. Ohno, N, Harada, T, Masuzawa, S, Miura, NN, Adachi, Y, Nakajima, M, Yadomae, T. 2002. Antitumor activity and hematopoietic response of a b-glucan extracted from an edible and medicinal mushroom Sparassis crispa Wulf. Fr.(Aphyllophoromycetideae). International Journal of Medicinal Mushrooms; 4(1).

4. Ahlawat, O, Manikandan, K, Singh, M. 2016. Proximate composition of different mushroom varieties and effect of UV light exposure on vitamin D content in Agaricus bisporus and Volvariella volvacea. Mushroom Research; 25(1): 1-8.

5. Ferreira, IC, Barros, L, Abreu, R. 2009. Antioxidants in wild mushrooms. Current Medicinal Chemistry; 16(12): 1543-1560.

6. TUIK Bitkisel Üretim İstatistikleri, Başka yerde sınıflandırılmamış diğer sebzeler, 1988-2017. 2018, Retrieved from http://www.tuik.gov.tr/PreTablo.do?alt id=1001 Last accessed date: 16.11 .2018

7. Wu, T, Xu, B. 2015. Antidiabetic and antioxidant activities of eight medicinal mushroom species from China. International Journal of Medicinal Mushrooms; 17(2).

8. Sevindik, M. 2018. Investigation of oxidant and antioxidant status of edible mushroom Clavariadelphus truncatus. Mantar Dergisi; 9(2): $165-168$

9. Papenfort, K, Bassler, BL. 2016. Quorum sensing signal-response systems in Gram-negative bacteria. Nature Reviews Microbiology; 14(9): 576.

10. Alves, MJ, Ferreira, IC, Lourenço, I, Costa, E, Martins, A Pintado, M. 2014. Wild mushroom extracts as inhibitors of bacterial biofilm formation. Pathogens; 3(3): 667-679.

11. Wayne, PA. 2012. Performance Standards for Antimicrobial Disk Susceptibility Tests; Approved Standard-Eleventh Edition. CLSI document M02-A11. Clinical and Laboratory Standards Institute.

12. Kaufman, SC, Ceraso, D, Schugurensky. 1986. A First case report from Argentina of fatal septicemia caused by Chromobacterium violaceum. Journal of Clinical Microbiology; 23(5): 956-958.

13. Gürgen, A, Yildiz, S, Can, Z, Tabbouche, S, Kilic, AO. 2018 Antioxidant, antimicrobial and anti-quorum sensing activities of some wild and cultivated mushroom species collected from Trabzon, Turkey. Fresenius Environmental Bulletin; 27(6): 4120 4131 .

14. Zhu, H, He, CC, Chu, QH. 2011. Inhibition of quorum sensing in Chromobacterium violaceum by pigments extracted from Auricularia auricular. Letters In Applied Microbiology; 52(3): 269-274.
15. Zhu, H, Sun, S. 2008. Inhibition of bacterial quorum sensingregulated behaviors by Tremella fuciformis extract. Current Microbiology; 57(5): 418 .

16. Glamočlija, J, Ćirić, A, Nikolić, M, Fernandes, Â, Barros, L, Calhelha, RC, Ferreira, IC, Soković, M, Van Griensven, LJ. 2015. Chemical characterization and biological activity of Chaga (Inonotus obliquus), a medicinal "mushroom". Journal of Ethnopharmacology; 162: 323-332.

17. Soković, M, Ćirić, A, Glamočlija, J, Nikolić, M,van Griensven, LJ. 2014. Agaricus blazei hot water extract shows anti quorum sensing activity in the nosocomial human pathogen Pseudomonas aeruginosa. Molecules; 19(4): 4189-4199.

18. Çapar, Y. 2002. Yeni ve yeniden önem kazanan infeksiyon hastalıkları. Güncel Gastroenteroloji; 6(1): 3543.

19. Liu, K, Xiao, X, Wang, J, Chen, CYO, Hu, H. 2017. Polyphenolic composition and antioxidant, antiproliferative, and antimicrobial activities of mushroom Inonotus sanghuang. LWT-Food Science and Technology; 82: 154-161.

20. Kaygusuz, O, Kaygusuz, M, Dodurga, Y, Seçme, M, Herken, EN, Gezer K. 2017. Assessment of the antimicrobial, antioxidant and cytotoxic activities of the wild edible mushroom Agaricus lanipes (FH Møller \& Jul. Schäff.) Hlaváček. Cytotechnology; 69(1): 135-144.

21. Klančnik, A, Megušar, $P$, Sterniša, M, Jeršek, B, Bucar F, Smole Možina S, Kos J, Sabotič J. 2017. Aqueous extracts of wild mushrooms show antimicrobial and antiadhesion activities against bacteria and fungi. Phytotherapy Research; 31(12): 1971-1976. 